\title{
A magyar védelmi kiadások trendjei, 2004-2019
}

\begin{abstract}
Oroszország Ukrajna elleni agressziója (2014) óta ismét a közös védelem kérdései kerültek a közép-európai NATO-tagállamok stratégiai párbeszédének középpontjába. A katonai képességek és készenlét megerősitése a kollektív védelem rendszerén belül sokat követel tölük stratégiai gondolkodásuk, védelmi tervezésük, katonai beszerzéseik és haderő-modernizációs programjaik összehangolása terén - és mindezek megalapozásához a védelmi kiadások növelése tekintetében. Donald Trump amerikai elnök kritikája nyomán, amely „fair” tehermegosztást követel, a szövetség tagállamainak vezetői már 2014-ben elfogadták a Transzatlanti Kötelékről szóló Walesi Nyilatkozatot (The Wales Declaration on the Transatlantic Bond) ${ }^{1}$, és ebben elkötelezték magukat védelmi kiadásaik növelése mellett (Defense Pledge). A tanulmány Magyarország honvédelmi kiadásainak trendjeiről ad átfogó képet a 2004-es EU-csatlakozás óta eltelt 15 évben. ${ }^{2}$
\end{abstract}

Kulcsszavak: Magyarország, védelmi költségvetés, védelempolitika, NATO, stratégia

\section{Csiki Varga Tamás: The Defence Expenditure Trends of Hungary, 2004-2019}

Defence has become a central issue of strategic discourse among NATO's Central European member states after 2014, following the Russian aggression against Ukraine. Reinforcing capabilities and readiness within the framework of collective defence requires much from these countries in terms of harmonising their strategic thinking, capability planning, defence procurement and modernisation - and as a central element to realising their aims, in terms of increasing funds for defence. U.S. President Donald Trump's criticism calling for 'more fair' burden sharing among member states, resulted in the adoption of The Wales Declaration on the Transatlantic Bond and member states' commitment to increase their defence expenditures (Defence Pledge). This paper offers a comprehensive analysis of Hungary's defence expenditure trends throughout the past 15 years, since the country's EU accession.

Keywords: Hungary, defence expenditure, defence policy, NATO, strategy

\footnotetext{
The Wales Declaration on the Transatlantic Bond, [online], 2014. 09. 05. Forrás: Nato.int [2019. 02. 10.]

A 2004-es EU-csatlakozás ideális kiindulópont a védelmi kiadások trendjeinek értékeléséhez, mivel a magyar biztonságpolitikai szakértők körében elfogadott az az álláspont, hogy a sikeres euroatlanti védelmi (NATO - 1999), illetve európai gazdasági-politikai integráció (EU - 2004) után a ország politikai és katonai elitje „elégedett volt” a stabil és biztonságos környezettel és figyelmüket - valamint az erőforrásokat - inkább más területekre irányították. Ennek hatása megmutatkozott abban is, hogy ezt követően egyre kevésbé mutatkozott hajlandóság arra, hogy védelmi célokra, a Magyar Honvédségre költsenek, az ország védelmi költségvetése pedig csökkent. Lásd például: TáLAs Péter: Negyedszázad magyar haderőreform-kísérleteinek vizsgálódási kereteiről. In: TáLAs Péter - CsıKı Tamás (szerk.): Magyar biztonságpolitika, 1989-2014 - Tanulmányok. NKE NI SVKK, Budapest, 2014, 18-19.
} 


\section{Korlátozott átláthatóság}

A magyar védelmi célú kiadásokra - hovatovább a Magyar Honvédség szervezetére, működési jellemzőire - vonatkozó adatok megismerése napjainkban sajnos erősen korlátozott. Mind a Honvédelmi Minisztérium, mind a Magyar Honvédség Parancsnoksága a lehető legnagyobb mértékben visszafogott a tájékoztatás terén a nyilvánosság számára saját kommunikációjában is, és 2011 óta a Honvédelmi Törvény módosításai rendkívül szűkre szabják az adatokhoz való hozzáférés lehetőségét: „A Honvédség szervezeti felépítésére, müködésére, haditechnikai eszközeire és anyagaira, valamint hadfelszerelésére vonatkozó adatok a keletkezésüktől számított 30 évig honvédelmi és nemzetbiztonsági érdekből nem nyilvánosak. Ezen adatok megismerését a honvédelmi és a nemzetbiztonsági érdek mérlegelésével a Magyar Honvédség parancsnokának javaslata alapján a honvédelemért felelős miniszter engedélyezheti." Í Igy nyílt forrású adatokra és információkra csak a minimális átláthatóság törvényi keretei között lelhetünk. ${ }^{4}$

Úgy véljük, hogy mivel az átláthatóság és elszámoltathatóság, valamint a társadalom irányában vállalt felelösség irányelveit nem vethetjük el, még a honvédelemmel kapcsolatos információk nemzetbiztonsági érzékenységét szem előtt és tiszteletben tartva is szükség lenne az alapvető adatok racionális megosztását biztosítani legalább olyan szinten, mint az a Honvédelmi Törvény 2011-es módosítását megelözően történt. Az információmegosztásnak ugyanis - a kutatói ambíciók elősegítésén túlmenően - számos gyakorlati előnye van: fokozhatja a társadalmi és szakpolitikai párbeszédet, nagyobb láthatóságot, ezáltal legitimitást biztosít a társadalmi javak felhasználásához, általánosságban is a Magyar Honvédség működéséhez. A tényalapú kommunikáció fokozná a társadalmi tudatosságot a biztonsággal és védelemmel (belbiztonság, országvédelem) kapcsolatban, valamint erösítené a Magyar Honvédség társadalmi támogatottságát is. Nem utolsósorban a szövetséges országok is tisztább képet kaphatnának arról, hogy a magyar kormány, a Honvédelmi Minisztérium, valamint a Magyar Honvédség milyen rövid és középtávú tervekkel rendelkezik a következö évekre vonatkozóan, például milyen elképzelések mentén alakította ki és hajtja végre a haderőmodernizációs terveket, ezáltal is javítva a két- és többoldalú, regionális együttmüködés lehetőségeit is.

2011. évi CXIII. törvény a honvédelemről és a Magyar Honvédségről, valamint a különleges jogrendben bevezethető intézkedésekről, [online], 2011. 07. 27. Forrás: Net.jogtar.hu [2019. 02. 10.]

4 A jelen tanulmányban szereplő minden adat és információ nyílt forrásból származik - így a védelmi költségvetés sarokszámait a Parlament által jogszabályi kötelezettsége nyomán elfogadott költségvetési törvényekböl, zárszámadási törvényekből, illetve ezek honvédelmi fejezeteinek szöveges indoklásaiból ismerhettük meg. A következő évre vonatkozó költségvetési törvényt általában a tárgyév tavaszi parlamenti ülésszakának végén (június, július), míg a tárgyév költségvetési folyamatait lezáró és pénzügyi mérlegeit rögzítő zárszámadási törvényt a következő év végén (november, december) fogadja el a parlament. Így például a 2017-es év költségvetési törvényét 2016. június 24-én fogadták el, zárszámadási törvényét pedig 2018. november 27-én. Az elemzés ezekre, valamint a NATO által ugyancsak nyílt forrásból származó védelmi kiadási kimutatásokra építi értékelését és következtetéseit. Lásd: 2016. évi XC. törvény Magyarország 2017. évi központi költségvetéséről, [online], 2016. 06. 24. Forrás: Net.jogtar.hu [2019. 02. 10.] és 2018. évi LXXXIV. törvény a Magyarország 2017. évi központi költségvetéséről szóló 2016. évi XC. törvény végrehajtásáról, [online], 2018. 11. 27., Magyar Közlöny, 2018/194. sz., 34430. o. Forrás: Magyarkozlony.hu [2019. 02. 10.] 


\section{Védelmi kiadási trendek 2004-2019 között}

Miután megszerezték a NATO- és EU-csatlakozással járó biztonsági garanciákat és élvezhették a nemzetközi környezet közép-európai szempontból kevésbé turbulens időszakának „kényelmét”, az európai stabilitás és prosperitás gyümölcseit, az egymást követő magyar kormányok egyre kevésbé fordítottak figyelmet a védelem kérdésére. Ennek első jele az volt, hogy már 2004-ben az eredetileg jóváhagyott 347 milliárd forintos ${ }^{5}$ honvédelmi költségvetés helyett csupán 312 milliárd forintot folyósítottak a Honvédelmi Minisztérium és a Magyar Honvédség kiadásainak fedezésére. ${ }^{6}$ A balkáni és afganisztáni stabilizációs és válságkezelő szerepvállalás növekvő terhei mellett is a következő években átlagosan +/-10\%-os határon belül mozgott a magyar honvédelmi költségvetés nominális összege, és hat évvel később, 2010-ben is körülbelül ugyanazon a szinten (317,8 milliárd forint) állt, mint 2005-ben (1. ábra).

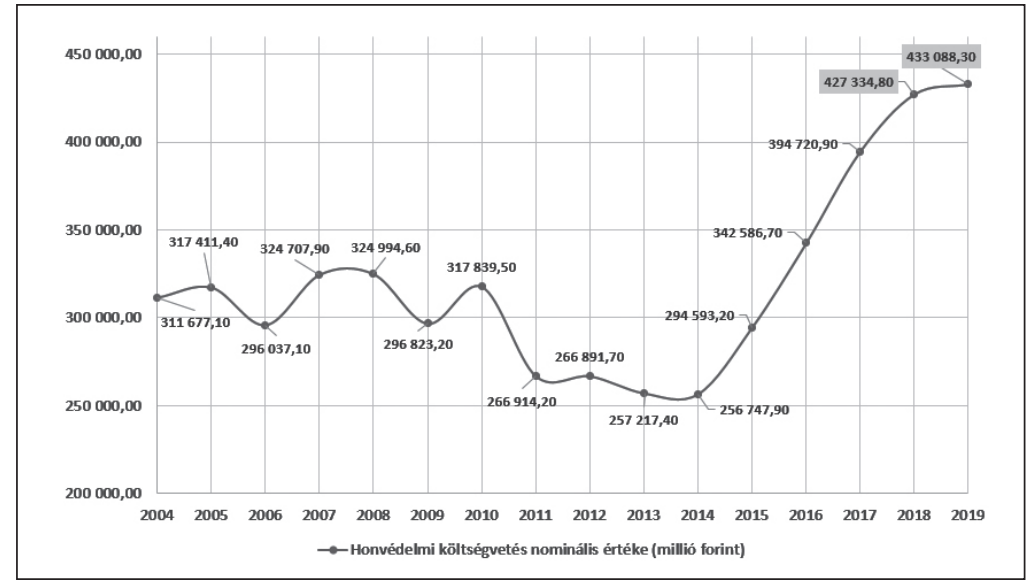

1. ábra: A magyar honvédelmi költségvetés változása nominálértéken 2004-2019 között

Forrás: a szerző szerkesztése

A 2008/2009-es pénzügyi-gazdasági válság közvetlen hatása 2010-ben a védelmi kiadások 16\%-os egyösszegű csökkentése volt, és a kismértékű csökkenés egészen 2014-ig folytatódott. Tíz évvel a magyar EU-csatlakozást követően a honvédelmi költségvetés nominális összege 17,6\%-kal volt alacsonyabb, mint 2004-ben, nem beszélve ennek az összegnek a reálértékű veszteségéről a védelmi inflációnak köszönhetően, amelynek becsült mérté-

A tanulmányban szereplő valamennyi összeg az adott év aktuális árfolyamán, nominálértéken értendő.

2005. CXVIII. törvény a Magyar Köztársaság 2004. évi költségvetéséről és az államháztartás hároméves kereteiről szóló 2003. évi CXVI. törvény végrehajtásáról. [online], 2005. 11. 11. Forrás: Net.jogtar.hu [2019. 02. 10.]

7 Az adatok forrása: 2004-2017 közötti zárszámadási törvények. A 2018-2019-es (színezéssel kiemelt) évekre az adatok forrása a költségvetési törvény, mivel még nem készült zárszámadás. (Tételesen lásd a felhasznált irodalmak jegyzékét.) 
ke mindig meghaladja a „normál” fogyasztói inflációt. ${ }^{8}$ Nem véletlen, hogy ez az évtized a hadrafoghatóság csökkenését és egyes képességek elvesztését eredményezte, különösen 2009 után - miközben modernizációra alig került sor.

2012-től vette kezdetét a normalizáció, majd három lépésben fokozatos elmozdulás következett a védelmi kiadások növelése felé:

- Az 1046/2012. sz. Korm. határozat ${ }^{9}$ elfogadásának célja az volt, hogy megállítsa a csökkenést, és legalább nominálértéken szinten tartsa a honvédelmi költségvetést 20132015 között, majd 2022-ig a nemzeti össztermék (GDP) arányában évi 0,1\%-os növekedéssel 1,39\%-os arányra növelje azt. Ennek ellenére 2013-2014-ben még nominális csökkenés történt, bár lassuló tendenciával, és a mélypontot 2014-ben, 256,75 milliárd forint összeggel érte el a védelmi költségvetés. Akkorra honvédelmi célokra mintegy 54,5 milliárd forinttal (17,5\%-kal) kevesebbet költöttek, mint 2004-ben.

- A nominális emelkedés 2015-ben kezdődött, egyszeri 14,74\%-os növekménynyel. Annak érdekében, hogy a folyamat hosszú távú eredményességét támogassák - és megfeleljenek a NATO-szövetségesi elvárásoknak - az 1273/2016. sz. Korm. határozat ${ }^{10}$ a GDP arányában évi 0,1\%-os növekedés időszakát kiterjesztette a 2017 2026-os időszakra, amelynek a végén 1,79\%-os arányt érnek el a honvédelmi kiadások a magyar költségvetésen belül.

- A továbbra is fennálló politikai nyomás a NATO részéról, valamint a Zrínyi 2026 Honvédelmi és Haderőfejlesztési Program forrásigénye a következő lépésben azt is megkövetelte, hogy a kormány az 1283/2017. sz. Korm. határozattal ${ }^{11}$ arról döntsön, hogy a NATO által elvárt 2\%-os GDP-arányt a védelmi kiadások tekintetében 2024-re el kívánja érni, majd 2025-től fenn is kívánja tartani.

2016-ban (16,29\%) és 2017-ben (15,22\%) újabb jelentős növekedést láthattunk, és a 2018-as, valamint 2019-es költségvetési törvények is a honvédelmi kiadások további növelését tették lehetővé, bár már szerényebb mértékben (2. ábra). Nominálértéken a magyar védelmi kiadások 2014-es legalacsonyabb szintjükhöz képest 2019-re 70\%-kal növekedtek.

8 A védelmi infláció az a mutató, amely egy termék vagy szolgáltatás egységárának változását mutatja adott időszakon belül a védelmi szektorban. A tapasztalat azt mutatja, hogy e termékek (például haditechnikai eszközök) és szolgáltatások (logisztika, müködésfenntartás) speciális jellegüknél fogva ugyanazon időszak alatt általában nagyobb mértékben drágulnak, mint a civil szektorban érzékelhető infláció. A nominálérték (névleges összeg) és reálérték (vásárlőerő) közti különbséget ez tovább növelheti.

9 1046/2012. Korm. határozat a honvédelmi kiadások és a hosszú távú tervezés feltételeinek megteremtését szolgáló költségvetési források biztosításáról, [online], 2012. 02. 29., 5340. o. Forrás: Kozlonyok.hu [2019. 02. 10.]

$10 \quad 1273 / 2016$. Korm. határozat a honvédelmi kiadások és a hosszú távú tervezés feltételeinek megteremtését szolgáló költségvetési források biztosításáról, [online], 2016. 06. 07. Forrás: Net.jogtar.hu [2019. 02. 10.]

11 1283/2017. Korm. határozat a honvédelmi kiadások és a hosszú távú tervezés feltételeinek megteremtését szolgáló költségvetési források biztosításáról szóló 1273/2016. Korm. határozat módosításáról, [online], 2017. 06. 02. Forrás: Net. jogtar.hu [2019. 02. 10.] 


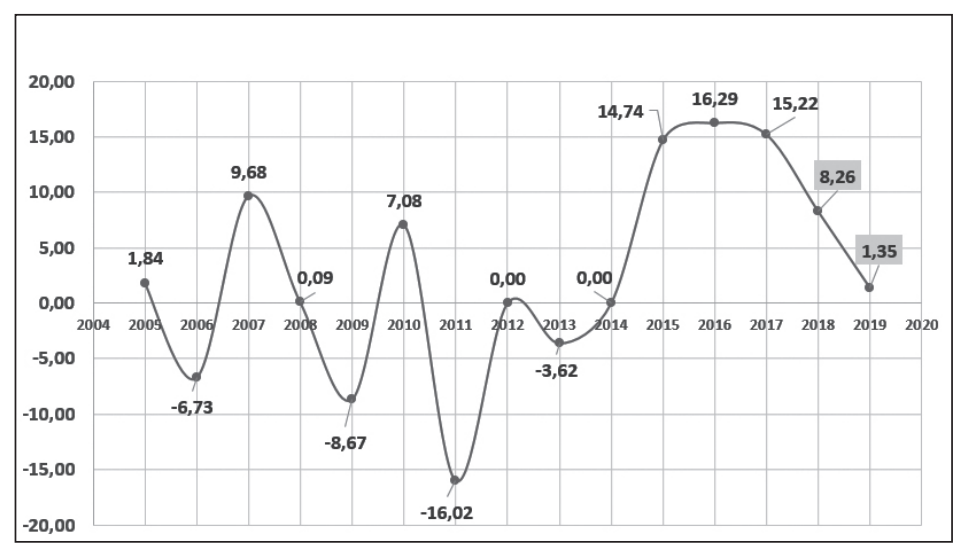

2. ábra: A honvédelmi költségvetés változása az előző évhez képest (\%)

Forrás: a szerző szerkesztése ${ }^{12}$

A 2004-2014 közötti időszakban a védelmi kiadások GDP-arányosan is csökkenő trendet követtek, pillanatnyi megtorpanásokkal 2007-ben és 2010-ben, majd 2014-ben érték el a mélypontot a nemzeti össztermék 0,79\%-ával (3. ábra). Azóta folyamatos a honvédelmi kiadások arányának növekedése is, ami a GDP teljes összegének növekedésével párhuzamosan (4. ábra) igen jelentős nominális növekedést jelent a gyakorlatban, mint azt az 1. ábrán számszerüsítve is láthattuk.

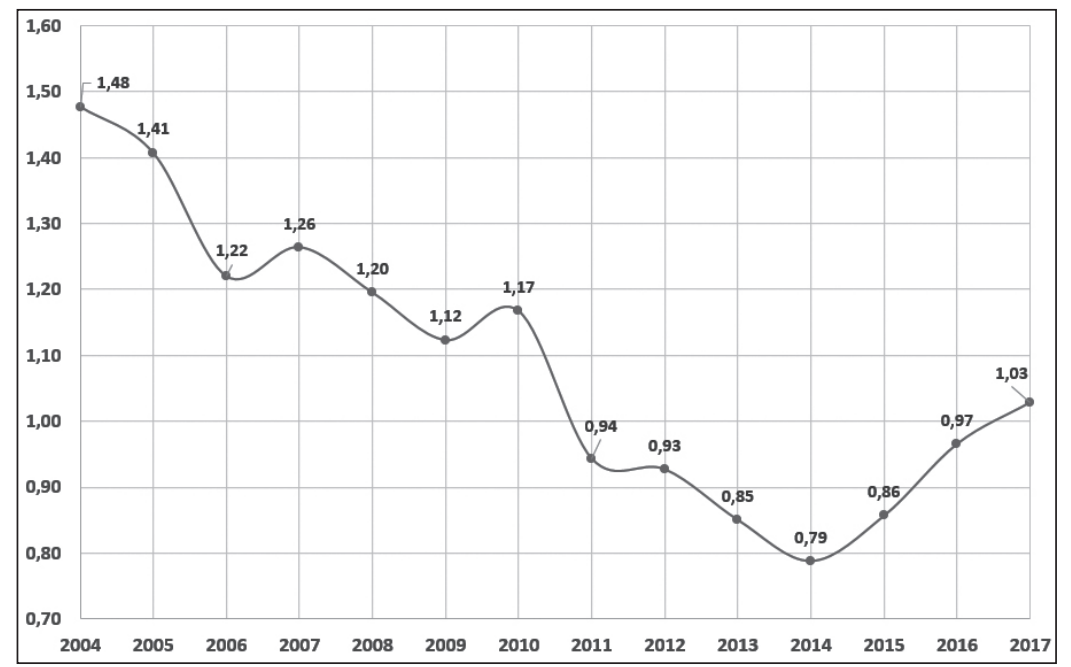

3. ábra: A magyar védelmi költségvetés változása a GDP-arányában 2004-2017 között (\%)

Forrás: a szerző szerkesztése ${ }^{13}$

12 Az adatok forrása: 2004-2017 közötti zárszámadási törvények. A 2018-2019-es (színezéssel kiemelt) évekre az adatok forrása a költségvetési törvény, mivel még nem készült zárszámadás. (Tételesen lásd a felhasznált irodalmak jegyzékét.)

13 Az adatok forrása: 2004-2017 közötti zárszámadási törvények. (Tételesen lásd a felhasznált irodalmak jegyzékét.) A GDP-adatok forrása: A bruttó hazai termék (GDP) értéke és volumenindexei (2000-), [online]. Forrás: Ksh.hu [2019. 02. 10.]. A 2017-es adat a KSH becslése; a 2018-2019-es évekre még nem rendelkezünk adatokkal. 


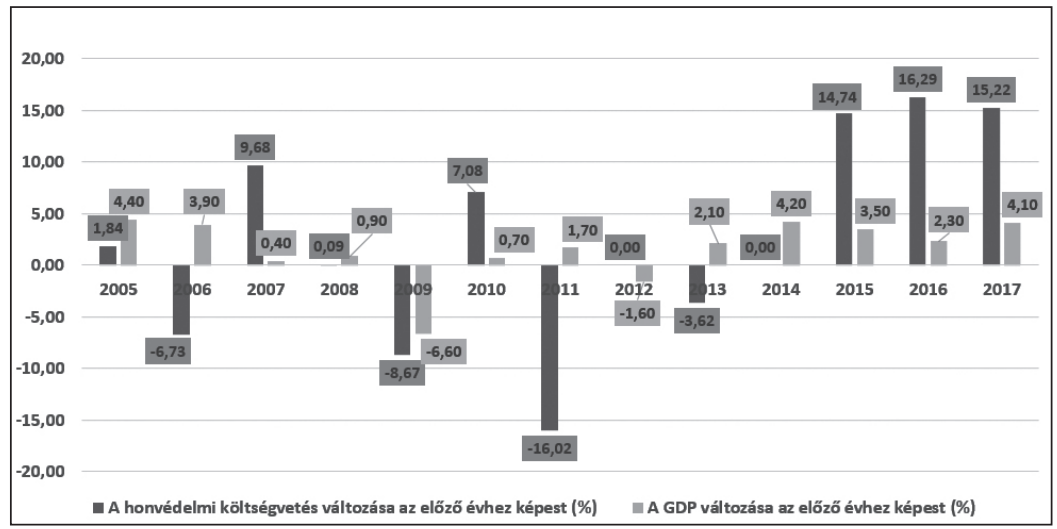

\section{4. ábra: A védelmi kiadások és a GDP változásának együttmozgása 2005-2017 között}

Forrás: a szerző szerkesztése ${ }^{14}$

\section{Elörejelzés és illusztratív forgatókönyvek}

A védelmi kiadások jövőbeli trendjeit illetően illusztratív forgatókönyveket vázolhatunk annak érdekében, hogy fel tudjuk mérni, milyen feltételekkel teljesülhet a (ma már) 2024-re kitüzött cél, hogy a magyar honvédelmi költségvetés elérje a nemzeti össztermék $2 \%$-os szintjét. A következőkben négy ilyen forgatókönyvet mutatunk be két változó függvényében: 1. a GDP-növekedés prognózisa alacsony és magas növekedési ráta mellett, valamint 2 . a védelmi költségvetés növelésének alacsonyabb és magasabb üteme mellett. A GDP-növekedés alacsony értékét a 2004-2017 közötti időszak átlagos GDPnövekedésének vesszük (1,8\%), ugyanis ebben a „kedvezőtlen” időszakban a magyar gazdaságnak strukturális problémák mellett a 2008/2009-es gazdasági válság hatásaival is meg kellett birkóznia. A GDP-növekedés magas értékéhez támpontot adhat a 2013-2017 közötti „kedvezö” öt év, amikor a magyar gazdaság túl tudott lépni a válság hatásain és lényegesen jobb eredményeket produkált, átlagosan 3,24\%-os növekedéssel..${ }^{15} \mathrm{~A}$ védelmi kiadások növelésére nézve az alacsony érték a 2012 óta tervezett éves 0,1\%, a magas pedig ennek duplája, éves $0,2 \%$.

14 Az adatok forrása: 2004-2017 közötti zárszámadási törvények. (Tételesen lásd a felhasznált irodalmak jegyzékét.) A GDP-adatok forrása: A bruttó hazai termék (GDP) értéke és volumenindexei (2000-), [online]. Forrás: Ksh.hu [2019. 02. 10.]. A 2017-es adat a KSH becslése; a 2018-2019-es évekre még nem rendelkezünk adatokkal.

15 Az illusztratív forgatókönyvekhez a Központi Statisztikai Hivatal GDP-adatait használtuk (a 2017-es adat a KSH becslése). A 2004-2017, illetve 2013-2017 közötti időszakokra statisztikai átlagot számoltunk és ezeket az átlagokat vetítettük előre a 2024-ig, illetve 2026-ig (a 2016-os vállalás határidejéig) terjedő időszakra a 2017-es bázisévhez képest. A GDPadatok forrása: A bruttó hazai termék (GDP) értéke és volumenindexei (2000-), [online]. Forrás: Ksh.hu [2019. 02. 10.]. A honvédelmi költségvetés elörejelzéséhez a 2019-es, költségvetési törvényben rögzített adat a kiindulópont. 
1. táblázat: Az alacsony GDP-növekedés és alacsony védelmi költségvetés-növekedés szerinti forgatókönyv

\begin{tabular}{|c|c|c|c|}
\hline I. forgatókönyv & 2024 & 2025 & 2026 \\
\hline $\begin{array}{l}\text { Teljes GDP-elörejelzés (millió forint) átlag 1,8\%-os éves } \\
\text { GDP-növekedés mellett 2026-ig }\end{array}$ & 43456799,19 & 44239021,58 & 45035323,97 \\
\hline A GDP honvédelemre költendő 2\%-a (millió forint) & 869135,98 & 884780,43 & 900706,48 \\
\hline $\begin{array}{l}\text { A védelmi költségvetés nominálértéke (millió forint) } \\
\text { éves 0,1\%-os GDP-arányú növekedés mellett }\end{array}$ & 642823,05 & 687062,07 & 732097,39 \\
\hline Teljesül a 2\%-os szint? & $1,48 \%$ & $1,55 \%$ & $1,63 \%$ \\
\hline
\end{tabular}

Forrás: a szerző szerkesztése

\section{2. táblázat: A magas GDP-növekedés és alacsony védelmi költségvetés-növekedés szerinti forgatókönyv}

\begin{tabular}{|c|c|c|c|}
\hline II. forgatókönyv & 2024 & 2025 & 2026 \\
\hline $\begin{array}{l}\text { Teljes GDP-előrejelzés (millió forint) átlag 3,24\%-os éves } \\
\text { GDP-növekedés mellett 2026-ig }\end{array}$ & 47946809,48 & 49500286,11 & 51104095,38 \\
\hline A GDP honvédelemre költendő 2\%-a (millió forint) & 958936,19 & 990005,72 & 1022081,91 \\
\hline $\begin{array}{l}\text { A védelmi költségvetés nominálértéke (millió forint) } \\
\text { éves 0,1\%-os GDP-arányú növekedés mellett }\end{array}$ & 658239,99 & 707740,28 & 758844,38 \\
\hline Teljesül a 2\%-os szint? & $1,37 \%$ & $1,43 \%$ & $1,49 \%$ \\
\hline
\end{tabular}

Forrás: a szerző szerkesztése

\section{3. táblázat: A magas GDP-növekedés és magas védelmi költségvetés-növekedés szerinti forgatókönyv}

\begin{tabular}{|c|c|c|c|}
\hline III. forgatókönyv & 2024 & 2025 & 2026 \\
\hline $\begin{array}{l}\text { Teljes GDP-elörejelzés (millió forint) átlag 3,24\%-os éves } \\
\text { GDP-növekedés mellett 2026-ig }\end{array}$ & 47946809,48 & 49500286,11 & 51104095,38 \\
\hline A GDP honvédelemre költendő 2\%-a (millió forint) & 958936,1896 & 990005,7222 & 1022081,91 \\
\hline $\begin{array}{l}\text { A védelmi költségvetés nominálértéke (millió forint) } \\
\text { éves } 0,2 \% \text {-os GDP-arányú növekedés mellett }\end{array}$ & 883391,68 & 982392,26 & 1084600,46 \\
\hline Teljesül a 2\%-os szint? & $1,84 \%$ & $1,98 \%$ & $2,12 \%$ \\
\hline
\end{tabular}

\section{4. táblázat: Az alacsony GDP-növekedés és magas védelmi költségvetés-növekedés szerinti forgatókönyv}

\begin{tabular}{|l|c|c|c|}
\cline { 2 - 4 } \multicolumn{1}{l|}{ IV. forgatókönyv } & 2024 & 2025 & 2026 \\
\hline $\begin{array}{l}\text { Teljes GDP-elörejelzés (millió forint) átlag 1,8\%-os éves } \\
\text { GDP-növekedés mellett 2026-ig }\end{array}$ & 43456799,19 & 44239021,58 & 45035323,97 \\
\hline A GDP honvédelemre költendö 2\%-a (millió forint) & 869135,98 & 884780,43 & 900706,48 \\
\hline $\begin{array}{l}\text { A védelmi költségvetés nominálértéke (millió forint) éves } \\
\text { 0,2\%-os GDP-arányú növekedés mellett }\end{array}$ & 852557,80 & 941035,84 & 1031106,48 \\
\hline Teljesül a 2\%-os szint? & $1,96 \%$ & $2,13 \%$ & $2,30 \%$ \\
\hline
\end{tabular}

Forrás: a szerző szerkesztése 
Mint ahogy azt az 5. táblázat összegzi, a GDP-növekedés ütemétől függetlenül nem teljesül a 2\%-os GDP-arányos szint sem 2024-ig, sem 2026-ig, amennyiben az éves védelmi költségvetés-növekedés csak a jelenleg tervezett 0,1\% lesz. Az intenzívebb, éves 0,2\%-os növekedési forgatókönyv esetében az alacsonyabb GDP-növekedés (1,8\%) mellett 2025-ben, a magasabb (3,24\%) esetén 2026-ban érheti el a magyar védelmi költségvetés nominális értéke a nemzeti össztermék 2\%-át, ezzel teljesítve a NATO irányában tett politikai vállalást.

\section{5. táblázat: Négy illusztratív forgatókönyv, amelyek alacsony és magas GDP-növekedési, illetve védelmi költségvetés-növekedési lehetöségekkel számolnak}

\begin{tabular}{|l|l|l|}
\cline { 2 - 3 } \multicolumn{1}{c|}{} & $\begin{array}{l}\text { a) } \mathbf{1 , 8 \% - 0 s} \text { GDP-növekedés } \\
\text { (a 2004-2017 évek átlaga) }\end{array}$ & $\begin{array}{l}\text { b) 3,24\%-os GDP-növekedés } \\
\text { (a 2013-2017 évek átlaga) }\end{array}$ \\
\hline $\begin{array}{l}\text { i) A védelmi költségvetés éves } \\
\mathbf{0 , 1 \% - o s ~ G D P - a r a ́ n y u ́ ~ n o ̈ v e k e d e ́ s e ~} \\
\text { mellett }\end{array}$ & $\begin{array}{l}\text { Az I. fogatókönyvben nem } \\
\text { teljesül a 2\%-os cél sem 2024-ig, } \\
\text { sem 2026-ig. }\end{array}$ & $\begin{array}{l}\text { A II. fogatókönyvben nem } \\
\text { teljesül a 2\%-os cél sem 2024-ig, } \\
\text { sem 2026-ig. }\end{array}$ \\
\hline $\begin{array}{l}\text { ii) A védelmi költségvetés éves } \\
\mathbf{0 , 2} \% \text {-os GDP-arányú növekedése } \\
\text { mellett }\end{array}$ & $\begin{array}{l}\text { A IV. fogatókönyvben 2024-ig } \\
\text { nem teljesül a 2\%-os cél, 2025- } \\
\text { ben azonban már igen. }\end{array}$ & $\begin{array}{l}\text { A III. fogatókönyvben 2024-ig } \\
\text { nem teljesül a 2\%-os cél, 2026- } \\
\text { ban azonban igen. }\end{array}$ \\
\hline
\end{tabular}

Forrás: a szerző szerkesztése

Bár e forgatókönyvek egy korábbi trend extrapolációján alapulnak, amelyek várhatóan nem folytatódnak lineárisan, a jelen helyzetben hasznos rávilágítanunk arra, hogy az aktuálisan kitűzött éves $0,1 \%$-os GDP-arányos védelmi költségvetés-növelés nem lenne elég a 2\%-os NATO-cél eléréséhez. Ugyanakkor a nominális növekedés bármely esetben igen jelentős lenne 2019-hez képest: az I. forgatókönyv alapján 69\%-os (732 097,39 millió forint), a II. forgatókönyv alapján 75,2\%-os (758 844,38 millió forint), a III. forgatókönyv alapján 138,1\%-os (1 031 106,48 millió forint), míg a IV. forgatókönyv szerint 150,43\%-os (1 084 600,46 millió forintra növelve a magyar honvédelmi költségvetést).

Végül azt is érdemes megemlíteni, hogy a 2004-2017 közötti időszak Zárszámadási törvényeinek tanulsága szerint a védelmi szféra végül átlagosan 9,2\%-os többletforrást kapott, mint amennyit a költségvetési törvény eredetileg meghatározott (5. ábra). Ez alapján feltételezhetjük, hogy a további években biztosított források is meghaladják majd az eredetileg tervezettet - valóban, 2018-ban az eredeti költségvetéshez képest további 72,0487 milliárd forintot kapott a védelmi tárca a központi költségvetésből, ${ }^{16}$ így összességében 512,8462 milliárd forintot, a becsült GDP 1,17\%-át ${ }^{17}$ fordíthatták védelmi célokra. ${ }^{18}$ Ennek nyomán az is elképzelhetö, hogy - a fent vázolt illusztratív forgatókönyvek közül három esetében teljesül a NATO által elvárt 2\%-os GDP-arány teljesítése.

16 A 2018-as honvédelmi költségvetési fejezet szöveges indoklása. XIII. Honvédelmi Minisztérium, [online]. Forrás: Parlament.hu [2019. 02. 10.]

17 A 2019-es honvédelmi költségvetési fejezet szöveges indoklása. XIII. Honvédelmi Minisztérium, [online]. Forrás: Parlament.hu [2019. 02. 10.]

18 Ezeket a tervezett többletforrásokat a 2. ábra kimutatása még nem tartalmazta, hiszen ezek változhatnak. E két év hivatalos mérlegét a zárszámadási törvények nyomán készíthetjük majd el, amelyeket várhatóan 2019, illetve 2020 végén fogad el a Parlament. 


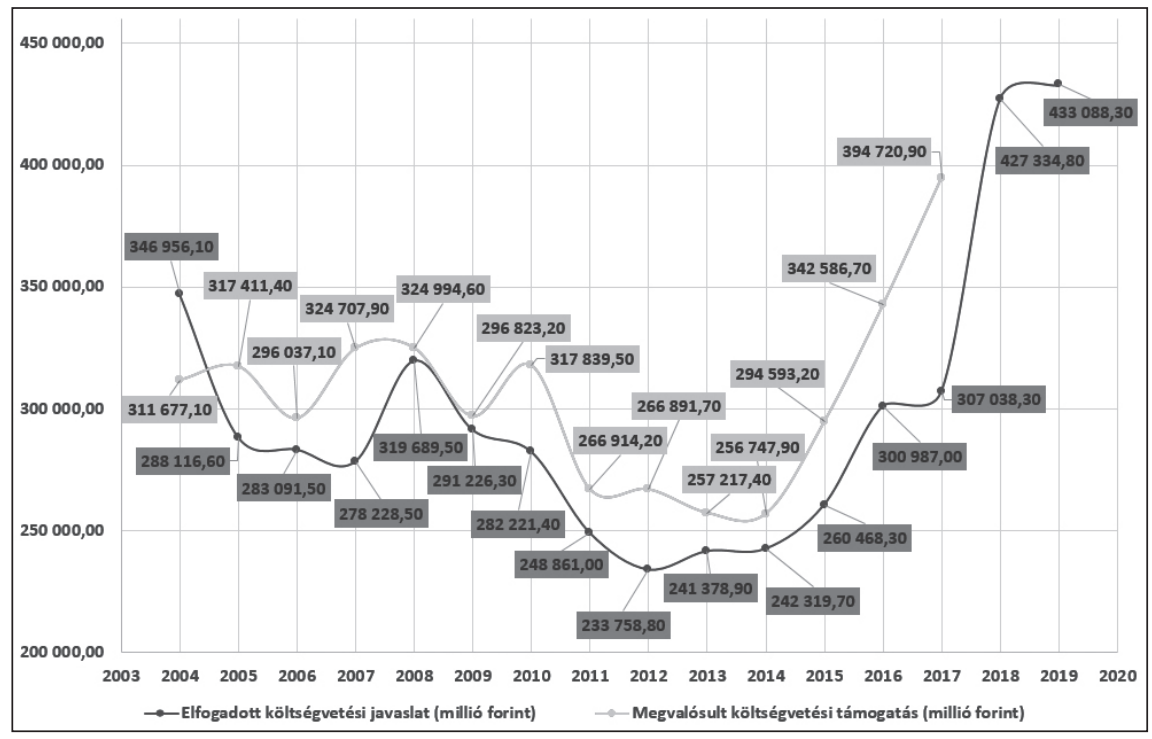

5. ábra: A honvédelmi költségvetés eredetileg tervezett (kék) és valójában felhasznált (piros) forrásai 2004-2019 között

Forrás: a szerző szerkesztése ${ }^{19}$

\section{Összegzett következtetések}

A védelmi szektorra fordított nagyobb figyelem és több forrás, valamint a felélénkült modernizáció egy átfogó normalizációs folyamat részét képezik Magyarországon, amely sok tekintetben azt szolgálja, hogy a meghaladott stratégiai és doktrinális megközelítéseket, illetve a leamortizálódott, elöregedett haditechnikai eszközöket lecseréljék, illetve újra kialakítsák azokat a szükséges képességeket, amelyeket az elmúlt években feladtak, valamint megfordítsák azokat a trendeket, amelyek gyengítették a Magyar Honvédséget - így a politikai figyelem korábbi hiányát, a társadalom közömbösségét, a maradékelvü finanszírozást, valamint a technológiai elhanyagoltságot.

Láthattuk, hogy 2014-ben, 10 évvel az ország EU-csatlakozását követően a védelmi kiadások nominális értéke 17,6\%-kal volt alacsonyabb, mint a csatlakozás idején, 2004ben - nem beszélve az infláció, illetve védelmi infláció következtében elszenvedett reálértékü veszteségről.

A magyar védelmi kiadások nominális értékének növekedése 2015-ben kezdődött jelentős, $14,74 \%$-os emelkedéssel már abban az évben, és ezt a növekvő trendet azóta is megörizte. Annak érdekében, hogy megfeleljünk a továbbra is fennálló szövetségesi politikai elvárásoknak, és biztosítani tudjuk a „Zrínyi 2026” Honvédelmi és Haderőfejlesztési

19 Az adatok forrása: 2004-2017 közötti zárszámadási törvények. A 2018-2019-es évekre vonatkozóan csak a költségvetési törvényekben meghatározott adatok szerepelnek, mivel még nem készült zárszámadás. (Tételesen lásd a felhasznált irodalmak jegyzékét.) 
Programhoz szükséges erőforrásokat, a magyar védelmi költségvetés 2024-re el fogja érni a GDP-arányos 2\%-ot, 2025-től pedig az addig elért szinten marad. Nominálértékben 2019-re a magyar honvédelmi költségvetés 70\%-kal növekedett a 2014-es mélyponthoz képest.

Négy - az elemzésben részletesen bemutatott - jelzésértékü forgatókönyv szerint, amelyek a GDP-növekedés elmúlt években tapasztalt trendjei és a tervezett folyamatos évenkénti honvédelmi költségvetés-növelés mértéke alapján készültek, azt jelezhetjük elöre, hogy 0,2\%-os éves növekedési ütem mellett várható az, hogy alacsonyabb GDP-növekedés esetén 2025-re, az elmúlt 5 év magasabb növekedési átlagának fennmaradása esetén 2026-ra elérjük a védelmi kiadások NATO által elvárt 2\%-os GDP arányát.

A Magyar Honvédség számára a költségvetési törvényben elfogadott 2019-es költségvetési forrás 433,1 milliárd forint (1,35 milliárd euró) volt, amelyet további 79,7 milliárd forint (0,25 milliárd euró) támogatással egészítettek ki azóta - összesen meghaladva az 512,8 milliárd forint (1,6025 milliárd euró) összeget, avagy a 2019-re becsült GDP 1,17\%-át.

\section{FELHASZNÁLT IRODALOM}

1046/2012. Korm. határozat a honvédelmi kiadások és a hosszú távú tervezés feltételeinek megteremtését szolgáló költségvetési források biztosításáról, [online], 2012. 02. 29. Forrás: Kozlonyok.hu [2019. 02. 10.]

1273/2016. Korm. határozat a honvédelmi kiadások és a hosszú távú tervezés feltételeinek megteremtését szolgáló költségvetési források biztosításáról, [online], 2016. 06. 07. Forrás: Net.jogtar.hu [2019. 02. 10.]

1283/2017. Korm. határozat a honvédelmi kiadások és a hosszú távú tervezés feltételeinek megteremtését szolgáló költségvetési források biztosításáról szóló 1273/2016. Kormányhatározat módosításáról, [online], 2017. 06. 02. Forrás: Net.jogtar.hu [2019. 02. 10.]

2005. CXVIII. törvény a Magyar Köztársaság 2004. évi költségvetéséről és az államháztartás hároméves kereteiről szóló 2003. évi CXVI. törvény végrehajtásáról, [online], 2005. 11. 11. Forrás: Net.jogtar.hu [2019. 02. 10.]

2006. évi XCIX. törvény a Magyar Köztársaság 2005. évi költségvetéséről szóló 2004. évi CXXXV. törvény végrehajtásáról, [online], 2006. 11. 13. Forrás: Net.jogtar.hu [2019. 02. 10.]

2007. évi CXXVIII. törvény a Magyar Köztársaság 2006. évi költségvetéséről szóló 2005. évi CLIII. törvény végrehajtásáról, [online], 2007. 11. 05. Forrás: Net.jogtar.hu [2019. 02. 10.]

2008. évi LXXVIII. törvény a Magyar Köztársaság 2007. évi költségvetéséről szóló 2006. évi CXXVII. törvény végrehajtásáról, [online], 2008. 12. 04. Forrás: Net.jogtar.hu [2019. 02. 10.]

2009. évi CXXIX. törvény a Magyar Köztársaság 2008. évi költségvetéséről szóló 2007. évi CLXIX. törvény végrehajtásáról, [online], 2009. 12.10. Forrás: Net.jogtar.hu [2019. 02. 10.]

2010. évi XCVIII. törvény a Magyar Köztársaság 2009. évi költségvetéséről szóló 2008. évi CII. törvény végrehajtásáról, [online], 2010. 10. 18. Forrás: Net.jogtar.hu [2019. 02. 10.]

2011. évi CXIII. törvény a honvédelemről és a Magyar Honvédségről, valamint a különleges jogrendben bevezethető intézkedésekről, [online], 2011. 07. 27. Forrás: Net.jogtar.hu [2019. 02. 10.]

2011. évi CXXXIII. törvény a Magyar Köztársaság 2010. évi költségvetéséről szóló 2009. évi CXXX. törvény végrehajtásáról, [online], 2011. 10. 03. Forrás: Net.jogtar.hu [2019. 02. 10.]

2012. évi CLV. törvény a Magyar Köztársaság 2011. évi költségvetéséről szóló 2010. évi CLXIX. törvény végrehajtásáról, [online], 2012. 10. 25. Forrás: Net.jogtar.hu [2019. 02. 10.]

2013. évi CXCIII. törvény a Magyarország 2012. évi központi költségvetéséről szóló 2011. évi CLXXXVIII. törvény végrehajtásáról, [online], 2013. 11. 22. Forrás: Net.jogtar.hu [2019. 02. 10.]

2014. évi LXII. törvény a Magyarország 2013. évi központi költségvetéséről szóló 2012. évi CCIV. törvény végrehajtásáról, [online], 2014. 11.21. Forrás: Net.jogtar.hu [2019. 02. 10.] 
2015. évi CLXXII. törvény a Magyarország 2014. évi központi költségvetéséről szóló 2013. évi CCXXX. törvény végrehajtásáról, [online], 2015. 11. 16. Forrás: Net.jogtar.hu [2019. 02. 10.]

2016. évi CXXII. törvény a Magyarország 2015. évi központi költségvetéséről szóló 2014. évi C. törvény végrehajtásáról, [online], 2016. 11.21. Forrás: Net.jogtar.hu [2019. 02. 10.]

2017. évi CLXX. törvény a Magyarország 2016. évi központi költségvetéséről szóló 2015. évi C. törvény végrehajtásáról, [online], 2017. 12. 11. Forrás: Net.jogtar.hu [2019. 02. 10.]

2016. évi XC. törvény Magyarország 2017. évi központi költségvetéséről, [online], 2016. 06. 24. Forrás: Net. jogtar.hu [2019. 02. 10.]

2018. évi LXXXIV. Törvény a Magyarország 2017. évi központi költségvetéséröl szóló 2016. évi XC. törvény végrehajtásáról, [online], 2018. 11. 27., Magyar Közlöny, 2018/194. sz., 34430. o. Forrás: Magyarkozlony. hu [2019. 02. 10.]

2017. évi C. Törvény Magyarország 2018. évi központi költségvetéséről, [online], 2017. 06. 27. Forrás: Net. jogtar.hu [2019. 02. 10.]

2018. évi L. Törvény Magyarország 2019. évi központi költségvetéséről, [online], 2018. 07. 31. Forrás: Net. jogtar.hu [2019. 02. 10.]

A 2018-as honvédelmi költségvetési fejezet szöveges indoklása. XIII. Honvédelmi Minisztérium, [online]. Forrás: Parlament.hu [2019. 02. 10.]

A 2019-es honvédelmi költségvetési fejezet szöveges indoklása. XIII. Honvédelmi Minisztérium, [online]. Forrás: Parlament.hu [2019. 02. 10.]

A bruttó hazai termék (GDP) értéke forintban, euróban, dollárban, vásárlóerő-paritáson (1995-2017), [online]. Forrás: Ksh.hu [2019. 02. 10.]

A bruttó hazai termék (GDP) értéke és volumenindexei (2000-), [online]. Forrás: Ksh.hu [2019. 02. 10.]

T/503/857. sz. Törvényjavaslat Magyarország 2019. évi központi költségvetéséröl, [online], 2018. 07. 25. Forrás: Parlament.hu [2019. 02. 10.]

TÁLAs Péter: Negyedszázad magyar haderőreform-kísérleteinek vizsgálódási kereteiről. In: TÁLAS Péter - CsıKı Tamás (szerk.): Magyar biztonságpolitika, 1989-2014 - Tanulmányok. NKE NI SVKK, Budapest, 2014.

The Wales Declaration on the Transatlantic Bond, [online], 2014. 09. 05. Forrás: Nato.int [2019. 02. 10.] 